\title{
The short-break holiday: assessing its understanding in the Northern Territory, Australia
}

\author{
R. D. Sharma \\ School of Law and Business, Charles Darwin University, Australia
}

\begin{abstract}
The paper is based on a national study of the 'Short-break holiday market in Australia'. It was conducted on behalf of the Sustainable Tourism Cooperative Research Center (STCRC). The study relates to specific market segments and examined a range of issues including: consumer attitude and behavior of the short-break holiday market; destination choice sets of that market; market potential vis-à-vis other travel and leisure offerings; destination attributes. Primary data was obtained by conducting local focus groups with actual and potential short break tourists in the relevant areas, followed by interviews with local tourist associations and industry representatives regarding current market and product strategies and possible adjustments to the evolving economic conditions. A key finding (the focus of this paper) indicates significant conceptual divide between the demand and supply side responses in terms of their understanding of the dimensions and key issues of 'short break holidays'. Consumers view this in a very broad manner compared to a more precise definition provided by the industry stakeholders. This disparity has obvious implications in terms of the relevance of strategies deployed by the industry stakeholders.
\end{abstract}

Keywords: short break holidays, definition, Northern Territory, focus group.

\section{Introduction}

'Short break' has emerged as a significant holiday activity in various global market segments. In Australia 'destination marketing organisations' (DMO) aggressively promote key destinations for short break holidays. Many industry 
stakeholders including accommodation and transport providers have used short break holidays in their promotional campaigns.

Murphy et al. [1] argue that 'short-break holidays' are an expanding global phenomenon, attributed to more complex and stressful lifestyles within affluent societies. It is pertinent to note that most short-break holidays are undertaken in addition to the traditional annual family holiday. This therefore represents additional demand and opportunities for new tourism products. Short break holidays are motivated by consumers' desire to get away for a few days, away from home in a nearby regional or national destination for relaxation and fun.

Based on the history that spans more than 30 years, it is reasonable to intuitively assume that all stakeholders are fairly conversant with the specific attributes of 'short break' as a distinct tourism product. It seems logical also to assume that all stakeholders, particularly the demand and supply side stakeholders have a clear and consistent understanding of this product. It is assumed that consumers (representing the demand side) and industry (comprised of accommodation, transport and other service providers such as wholesalers etc.) have similar understanding of what 'short break' really means. Conceptual agreement between consumers and product providers is essential for 2 reasons: (1) development of appropriate products that meet consumer needs and wants and (2) to enhance promotional effectiveness for the end users and distribution channel members.

A review of literature reveals that 'short break' is defined and interpreted by different groups with significant variations. There appears a lack of conceptual understanding between the key stakeholders. The following definitions of 'short break' for example highlight the issue.

Table 1: $\quad$ Short break definitions.

\begin{tabular}{|l|l|}
\hline Author & Definition - Brief description \\
\hline STCRC Australia [2] & $\begin{array}{l}\text { Short break is a 'non-business' trip between 1 and 4 } \\
\text { nights away from the place of residence (home). }\end{array}$ \\
\hline $\begin{array}{l}\text { Tsiotsou and Vasioti } \\
{[3]}\end{array}$ & Short term vacation refer to 1 - 6 nights stay \\
\hline Huybers [4] & Short-break refer to a trip of 2-3 nights' duration \\
\hline Pike [5] & $\begin{array}{l}\text { A short break is a non-business trip of one to three } \\
\text { nights duration, away from the home environment. }\end{array}$ \\
\hline Fache [6] & $\begin{array}{l}\text { A short break is defined as a non-business trip of 1 to } \\
\text { 3 nights away. }\end{array}$ \\
\hline Lohmann [7] & $\begin{array}{l}\text { A short-break holiday is characterised by the duration } \\
\text { of the trip (up to 4 days, but at least one overnight } \\
\text { stay) }\end{array}$ \\
\hline
\end{tabular}

It is apparent from the foregoing that 'short break' lack a universal definition. There is limited agreement among authors as to what it really stands for. While there is agreement that it is a non-business trip, the duration of stay varies between various authors. Other attributes such as location, travel time, etc. do 
not feature in most definitions. The academic definitions cited above confirm that a common and coherent definition of 'short break' is currently unavailable. It is difficult to speculate the specific causes of the different definitions. Davies [8] however contends that the difficulty to determine what a short-break is, largely due to the travel industry itself is not prepared to agree on a definition. One is inclined to agree with Tsiotsou and Vasioti [3] that many aspects of 'short-term visitors remain unexplored - a view also shared by Pike and Ryan [9]. While it is widely accepted that 'short break holidays' can play a significant role in promoting a destination, limited understanding and investigation of 'short break' among key stakeholders is unhelpful in either theory building effort or industry guidance for improved practice.

\section{Research objectives}

Given the emergence of 'short break' as a significant travel activity in most western economies, there is clearly a need for more systematic research. Sustainable Tourism Cooperative Research Centre (STCRC) Australia initiated a major project on short break holidays in Australia. The major focus of the project was the development of 'a competitive destination strategy', with the goal of providing current and potential 'short-break' Australian destinations with some guidelines as to how to differentiate themselves and become more attractive to this market [1].

A key objective of the project was to gain the understanding of short break holiday from both supply and demand side stakeholders. The objective was to assess how well is 'short break' understood within the key stakeholders. This paper explores the level of stakeholder understanding.

\section{Methodology}

The national research team decided initially to use an exploratory qualitative methodology to assess the demand and supply side understanding of 'short break' in all key market segments of Australia. This paper is based on focus group and in-depth responses of demand and supply side participants of the Northern Territory of Australia. A focus group session was conducted with actual and potential short break customers in Darwin. The purpose of the focus group was to talk with people from the Northern Territory (predominantly Darwin) who had recently undertaken a short break holiday in Australia and others who may be considering such an option. The participants were identified and selected through a local newspaper advertisement in the Northern Territory. A total of 11 men and women took part in the focus group discussion. The participants brought a rich variety of backgrounds to the discussion and represented a broad range of demographic characteristics - 5 male and 6 female; well spread out age groups and family life cycle stages. A majority of respondents ( 8 out of 11) had recently undertaken short break holidays and were also planning to go in near future. 
Assessment of supply side understanding was based on 8 in-depth interviews that were conducted with industry representatives in Darwin and Alice Springs. Industry participants were represented by four sectors namely, accommodation, travel, industry associations and government.

\section{Findings}

The responses provided here have removed all references to individuals and organisations in order to protect the identity of the respondents. The focus group findings of demand side respondents are based on the pre specified general and regional issues.

- In terms of defining and or describing a short-break holiday, consumer responses varied quite significantly. This was irrespective of prior short break experience of the respondents. It was described within a very wide range of days - a weekend ( 2 days) to 3 weeks.

- Most consumer respondents were unconcerned with the number of destinations included in a short break holiday. It really did not matter if more than one destination was visited during the trip.

- Most respondents also accepted short break holidays as an adjunct or addon to a business trip.

- Similarly consumers did not differentiate between domestic and international short break holidays.

- The two major tourism hubs of Northern Territory (NT) (Darwin/Top End and Alice Springs/Central Australia) were perceived as distinct short break destinations. Darwin was described as uniquely tropical while Alice Springs as predominantly a desert destination.

- In addition to the differences in topography, the two tourist regions were viewed with very different histories and heritage and therefore the two were seen as non competing destinations.

- The other attributes identified included holidays with fun and entertainment; holiday away from home; break from normal schedule; escape from everyday life; break away from every day chores.

The supply side respondents indicated a much higher level of agreement within the industry group in terms of defining and describing short-break holidays.

- Almost the entire group viewed it fairly similarly in terms of the duration. All responses were within 3-5 days range.

- The level of understanding and consistency between the accommodation sector respondents was particularly high. 
- Many respondents highlighted that short break holidays mostly involved short haul flights. The preparation and lead-time taken to organize these holidays was also considered short or less elaborate.

- Travel sector respondents considered short break as a trip of no more than four days duration, usually over a long weekend; 3-5 days including the weekend.

- Short break holidays are meant exclusively for personal and family relaxation with no work related component. This is significantly different from the consumer understanding of adjunct or add-ons to business trips.

- With regards to the Northern Territory (NT), there was general agreement that the two key NT tourist destinations are quite different. Both have unique tourism attributes that in some way complement each other. Both are distinct and diverse landscapes - tropical savannah and desert and are independent of each other.

- Darwin is unique for fishing and nightlife and Alice Springs comes across as the capital of indigenous art and culture. Darwin has Kakadu and Alice Springs the big Rock - Uluru.

- The two NT destinations did not fit under the same marketing appeal and promotional campaign. Although the two destinations were not perceived to be in competition with each other, it was infeasible to combine the two for the purpose of marketing and promotion.

- According to Tourism Top End research the traditional perception barriers of time, distance and cost still applied in differentiating the two NT destinations.

\section{Discussion}

Short break has become a popular and widespread holiday option in Australia [1]. Many tourism products are now designed and packaged for the 'short break' segment. The principles of new product development and product modification suggest that industry stakeholders' understanding of short break' should drive product development in terms of specific attributes. In the present case it is unclear if the attributes of short break are aligned to consumer understanding as well. It is evident from the qualitative responses that the demand and supply groups are not aligned sufficiently in terms of what short break holidays constitute. Consumer and industry responses indicate a significant conceptual divide in terms of their basic understanding and specific dimensions of 'short break holidays'. NT consumers view short break holidays in a very broad manner compared to a more precise definition provided by the industry 
stakeholders. The understanding variance within the consumer group is much higher than the industry stakeholders. Overall, neither the consumers nor the industry has a clear and consistent idea of 'short break holidays' in the Northern Territory. It is relevant to highlight that this conceptual ambiguity is not limited to NT alone. Research by Murphy et al. [1] indicated that this applies more broadly to Australia as a whole.

Consumers consider 'short break' largely as a uni-dimensional product. 'Number of days' is the key attribute in their description of short break. Although as stated earlier, consumer responses vary significantly from 3 to 21 days. Industry respondents consider 'short break' as multi-dimensional construct. There is more uniformity in their description compared to the consumer group. The industry description however is also at variance with the definition provided by the academics.

The 'understanding incompatibility' is obvious at 3 levels: (1) among academics (as indicated by the definitions, (2) among practitioners and (3) among consumers. This divide and mutual incompatibility has obvious implications in terms of the relevance of strategies deployed by the industry stakeholders. It is an accepted practice that the composition of product attributes (both tangible and intangible) is largely dictated by 'target market' characteristics and expectation. Consumer emphasis on single dimension, ie, number of nights only, may suggest that this is a homogenous market segment. Consideration of additional features reported by the supply side stakeholders however indicates that short break is a more complex and heterogeneous market.

It is argued that destination performance is a function of a destination's capacity to deliver relevant benefits to the target market travellers. Destinations should offer appropriate attributes to their target markets. Mere possession of attractive attributes however does not guarantee the success of a destination [5]. In a congested product space, product differentiation is an important strategy to position competing tourist destination. However it is difficult to develop differentiated products if destination features are perceived as irrelevant by the target market or customers perceive inherent similarity in the competing product range.

\section{Conclusion}

Short break has emerged as a significant holiday activity in various global market segments for example in New Zealand [10], UK [11, 17], Europe [6, [12], USA [13], Australia [15] and Canada [16]. However the notion of 'short break holidays' is neither clear nor consistent in the cognitive domains of either consumers or industry stakeholders. Short break appears to lack an internationally recognised definition [5]. The widespread academic attention and its reporting in main stream media has allowed 'short term holiday' as an expression of a distinct tourism product to enter the popular lexicon. However 'short term' bas been interpreted quite widely in similar consumption contexts. Consumer definition is largely uni-dimensional that relies on 'number of nights' in a broad and imprecise manner. Industry on the other hand considers short 
break along a range of attributes. Number of nights; domestic or international; stand alone or coupled; and single or multiple destinations. The apparent lack of understanding is unhelpful in the development of competitive strategies that require collaborative effort for consumer analysis and product planning.

There have been suggestions made earlier that 'short break holidays' as a construct lacks an internationally recognised definition [5]. The description provided by different stakeholders confirms that industry lacks a common and coherent definition of 'short break'. Boerjan [14], however, has queried whether we need to differentiate between a short or long holidays. Whether the current situation is satisfactory in promoting short break holidays remains unresolved. It is therefore argued that the definition of short break should be reviewed. A tighter definition that captures the essential attributes in term of number of nights, number of definition etc. will facilitate future marketing of this unique tourism product in a more effective manner.

Supply of destination products globally has increased significantly. As a consequence, destination marketing organisations (DMO) are fiercely competing for consumer attention and their business. Given the multiplicity of the definitions and descriptions, it is essential that greater interaction and engagement between the academics and practitioners is facilitated to urgently address the inconsistencies. Short-break holiday-makers are a complex and varied group, not a single homogeneous market. In order to provide more appropriate product features, engagement between the key stakeholders is important for more balanced assessment.

\section{Acknowledgement}

We acknowledge the support and financial assistance provided by the 'Sustainable Tourism Cooperative Research Centre' (STCRC) of Australia in conducting this research.

\section{References}

[1] Murphy, Peter; Niininen, Outi and Sanders, Dale. Short-break holidays: A competitive destination strategy, CRC for Sustainable Tourism Pty Ltd, 2010 .

[2] STCRC Australia, http://www.crctourism.com.au/ viewed on 27 May 2010

[3] Tsiotsou, Rodoula and Vasioti, Eleytheria. Satisfaction: a segmentation criterion for 'short term' visitors of mountainous destinations. Journal of Travel and Tourism Marketing, 20 (1), pp 61 - 73, 2006.

Huybers, Twan. Domestic tourism destination choices - a choice modelling analysis. International Journal of Tourism Research 5 (6), pp 445 - 459, 2003.

[4] Pike, Steve. ToMA as a measure of competitive advantage for short-break holiday destinations. Journal of Tourism Studies, 13 (1), pp 9 - 19, 2002.

[5] Faché, Willy: Editor,. Short-break Holidays. Rotterdam, Netherlands: Centre Parcs, 1 - 109, 1990. 
[6] Lohmann, Martin Evolution of short-break holidays. The Tourist Review, 2, pp $14-23,1991$.

[7] Davies, B., The economics of short breaks. International Journal of Hospitality Management, 9 (2), pp 103 - 106, 1990.

[8] Pike, Steve and Ryan, Chris. Destination positioning analysis through a comparison of cognitive, affective and conative perceptions. Journal of Travel Research, 42 (4), pp333 - 342, 2004.

[9] Pike, Steve. The use of importance-performance analysis (IPA) to identify determinant short break destination attributes in New Zealand. Pacific Tourism Review, 6 (1), pp 23 - 33, 2002.

[10] Ryan, C., Modelling hotel strategies in the weekend break. Unpublished report. Nottingham, UK: Clarendon College, 1983.

[11] Faché, Willy. Short break holidays. In Witt, Steve and Moutinho, L. (eds) Tourism Marketing and Management Handbook (2nd Edition) Hertfordshire: Prentice Hall International, pp459 - 467, 1994.

[12] Plog, S., Thirty years that changed travel: Changes to expect over the next ten. Paper presented at the $31^{\text {st }}$ Travel and tourism research association conference, Burbank, CA, 2000.

[13] Boerjan, Paul, Do we need a distinction between short and long holidays? The Tourist Review, 2 (1), pp 11 - 17, 1995.

[14] Dwyer, Larry, Liviac, Z. and Mellor, R., Competitiveness of Australia as a tourist destination. Journal of Hospitality and Tourism Management, 10 (1), pp $60-78,2003$.

[15] Hudson, Simon and Ritchie, Brent. Understanding the domestic market using cluster analysis: a

case study of the marketing efforts of Travel Alberta. Journal of Vacation Marketing, 8 (3), 263 - 276, 2002.

[16] Middleton, Victor and O'Brien, K. Short break holidays in the UK. Travel and Tourism Analyst, May, pp 45 - 54, 1987. 